\title{
DESIGN OF INCONEL 706 FOR IMPROVED CREEP CRACK GROWTH RESISTANCE
}

\author{
J. Rösler, S. Müller, D. Del Genovese, M. Götting \\ Technical University Braunschweig, \\ Institute for Materials \\ D-38106 Braunschweig, Germany
}

\begin{abstract}
Creep crack growth data of Inconel $706-\mathrm{MST}$ between $600^{\circ} \mathrm{C}$ and $700^{\circ} \mathrm{C}$ are presented in order to assess the materials suitability for ultra high temperature steam turbine applications. Hereby, "MST" stands for a heat treatment modification proposed earlier by the authors. It is demonstrated that the creep crack growth resistance can be raised to the level of more creep ductile materials such as Waspaloy and Inconel 617 and that the benefit relative to conventional heat treatment cycles is particularly pronounced at $700^{\circ} \mathrm{C}$. The results are interpreted in terms of the precipitation sequence during thermal exposure.
\end{abstract}




\section{Introduction}

Inconel 706 is a wrought $\mathrm{Ni}-\mathrm{Fe}$ base superalloy which is widely used in the gas turbine industry, e.g. for disc applications, because of its balanced manufacturability and elevated temperature strength [1]. Amongst other wrought superalloys such as Inconel 617 and Waspaloy, it is also under consideration for operation in ultra high temperature steam turbines with prospective steam temperatures of about $700^{\circ} \mathrm{C}$ to $720^{\circ} \mathrm{C}$ and an anticipated thermal efficiency of approximately 55\% [2]. Interestingly, the latter application exceeds aerospace requirements in many respects and it is uncertain whether existing wrought superalloys will meet the requirements on manufacturability (ingot size of more than 10 tons), mechanical behavior and long term stability to 200000 hours of operation. For this reason, a research project supported by the "Deutsche Forschungsgemeinschaft" was set forth to elucidate the potential of current wrought superalloys with respect to
castability and forgeability of large ingots
long term stability of the microstructure
creep behavior
creep crack growth resistance

and to develop modified materials with improved property balance for ultra high temperature steam turbine applications. Fig. 1 illustrates the structure and partners of the research program.

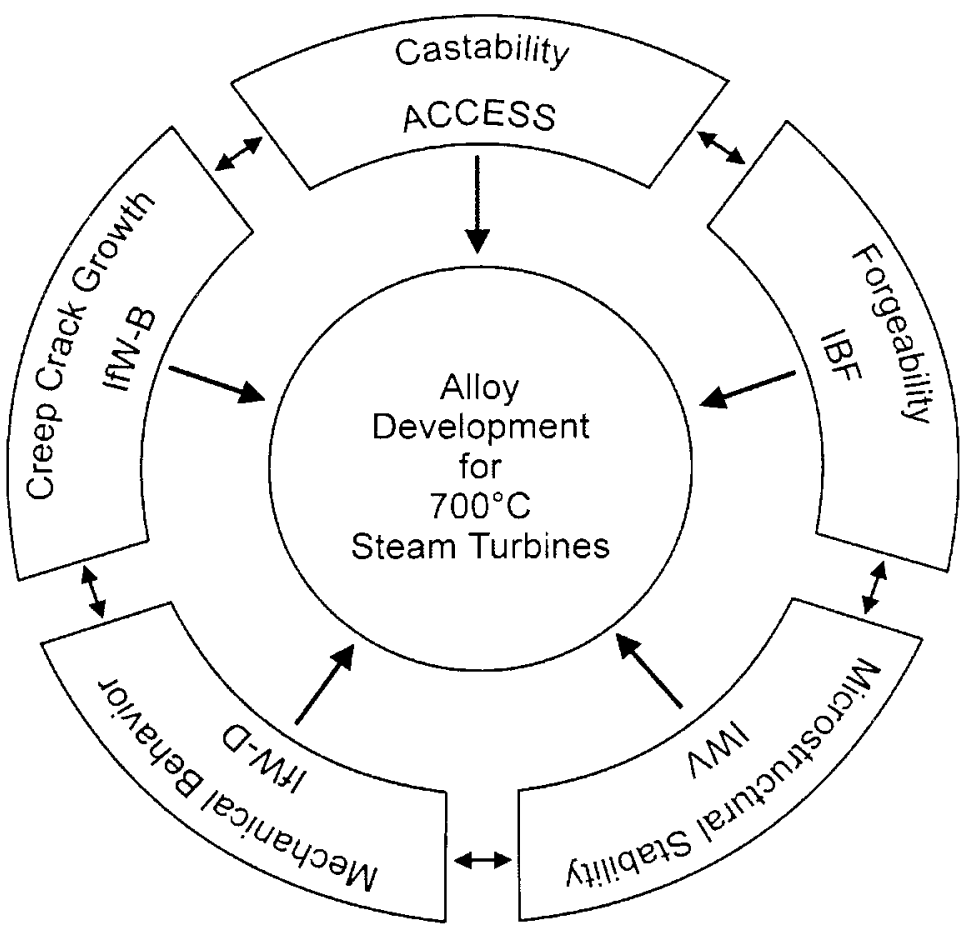

Fig. 1: Partners and tasks of the research program on advanced Ni-base superalloys for ultra high temperature steam turbine applications supported by the "Deutsche Forschungsgemeinschaft" (IfW-B: Institut für Werkstoffe, Technical University Braunschweig; IfW-D: Institut für Werkstoffkunde, Technical University Darmstadt; IWV: Institut für Werkstoffe und Verfahren der Energietechnik; Researchcenter Jülich; IBF: Institut für Bildsame Formgebung; Technical University Aachen; ACCESS: ACCESS e.V., Aachen) 
In this article, the focus is on creep crack growth resistance while creep behavior and long term microstructural stability are discussed in papers by Berger et al. and Schubert et al. in this conference proceeding. Creep crack growth is of relevance for steam turbine rotor applications as damage tolerance against initial flaw sizes below the detectability limit of ultrasonic inspection methods is an important design requirement. Furthermore, it is well known that Inconel 706 suffers from the so called SAGBO-phenomenon (SAGBO: stress accelerated grain boundary oxidation) as other comparable superalloys do [3-6]. Brittle intergranular fracture and an acceleration of the creep crack growth rate by two to three orders of magnitude relative to vacuum data are manifestations of the embrittlement by oxygen and, potentially, water vapour [6]. Typical crack growth rates of Inconel 706 at $600^{\circ} \mathrm{C}$ in air are shown in fig. 2 (data from [7]), comparing the two heat treatment types commonly used today (see table I). Measured crack velocities of more than $0.1 \mathrm{~mm} / \mathrm{h}$ at stress intensities as small as $30 \mathrm{MPam}^{1 / 2}$ are unacceptable for the above mentioned application.

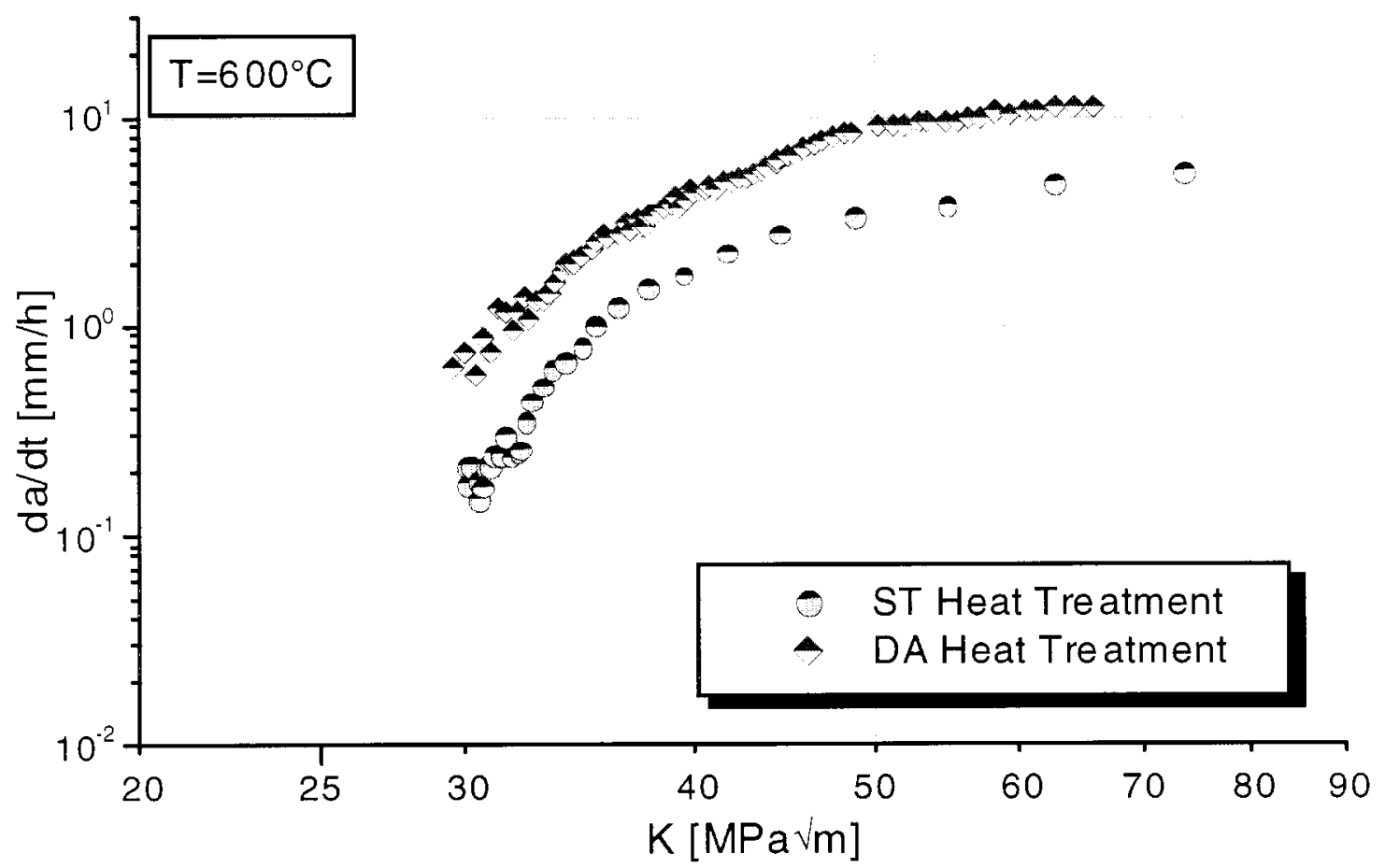

Fig. 2: Creep crack growth data of Inconel 706 at $600^{\circ} \mathrm{C}$ in DA and ST heat treatment condition according to table I (data from [7]).

Table I: Direct aging (DA) and stabilization (ST) heat treatment cycles for Inconel 706 (AC: air cooling; FC: furnace cooling).

\begin{tabular}{lcclrl}
\hline Heat Treatment & Solutioning & Stabilization & \multicolumn{2}{c}{ Precipitation Annealing } \\
\hline $\mathrm{DA}$ & $2 \mathrm{~h} / 980^{\circ} \mathrm{C} ; \mathrm{AC}$ & - & $8 \mathrm{~h} / 720^{\circ} \mathrm{C} ;$ with & $1 \mathrm{~K} / \mathrm{min}$ & to \\
& & & $8 \mathrm{~h} / 620^{\circ} \mathrm{C} ; \mathrm{FC}$ & & \\
& & & & \\
& & & & \\
$\mathrm{ST}$ & $2 \mathrm{~h} / 980^{\circ} \mathrm{C} ; 4 \mathrm{~K} / \mathrm{min}$ & $3 \mathrm{~h} / 850^{\circ} \mathrm{C} ; \mathrm{AC}$ & $8 \mathrm{~h} / 720^{\circ} \mathrm{C} ;$ with & $1 \mathrm{~K} / \mathrm{min}$ & to \\
& & & $8 \mathrm{~h} / 620^{\circ} \mathrm{C} ; \mathrm{FC}$ & & \\
\hline
\end{tabular}

The heat treatment referred to as direct aging (DA) in this artice (tab. I) leads to uniform precipitation of fine $\gamma^{\prime} / \gamma^{\prime \prime}$ particles with dimensions of about $20 \mathrm{~nm}$ (fig. 3b). In contrast, the stabilization (ST) heat treatment causes $\eta$-phase precipitation at grain boundaries during 
annealing at $850^{\circ} \mathrm{C}$ (fig. $3 \mathrm{c}, \mathrm{d}$ ). As some of the available $\mathrm{Ti}, \mathrm{Al}$ and $\mathrm{Nb}$ is consumed, less $\gamma^{\prime} / \gamma^{\prime \prime}$-phase is formed and, in consequence, the yield strength decreases from about $1085 \mathrm{MPa}$ (DA) to $979 \mathrm{MPa}$ in the fully heat treated ST condition. The ST treatment is generally considered as advantageous in applications were long term creep strength rather than yield strength is required because of better microstructural stability and grain boundary decoration with $\eta$-phase. This phase is believed to prevent grain boundary cracking. However, the data shown in fig. 2 do not support this expectation as far as resistance against creep crack growth is concerned. Even though there is some benefit, it is insufficient for the intended application.
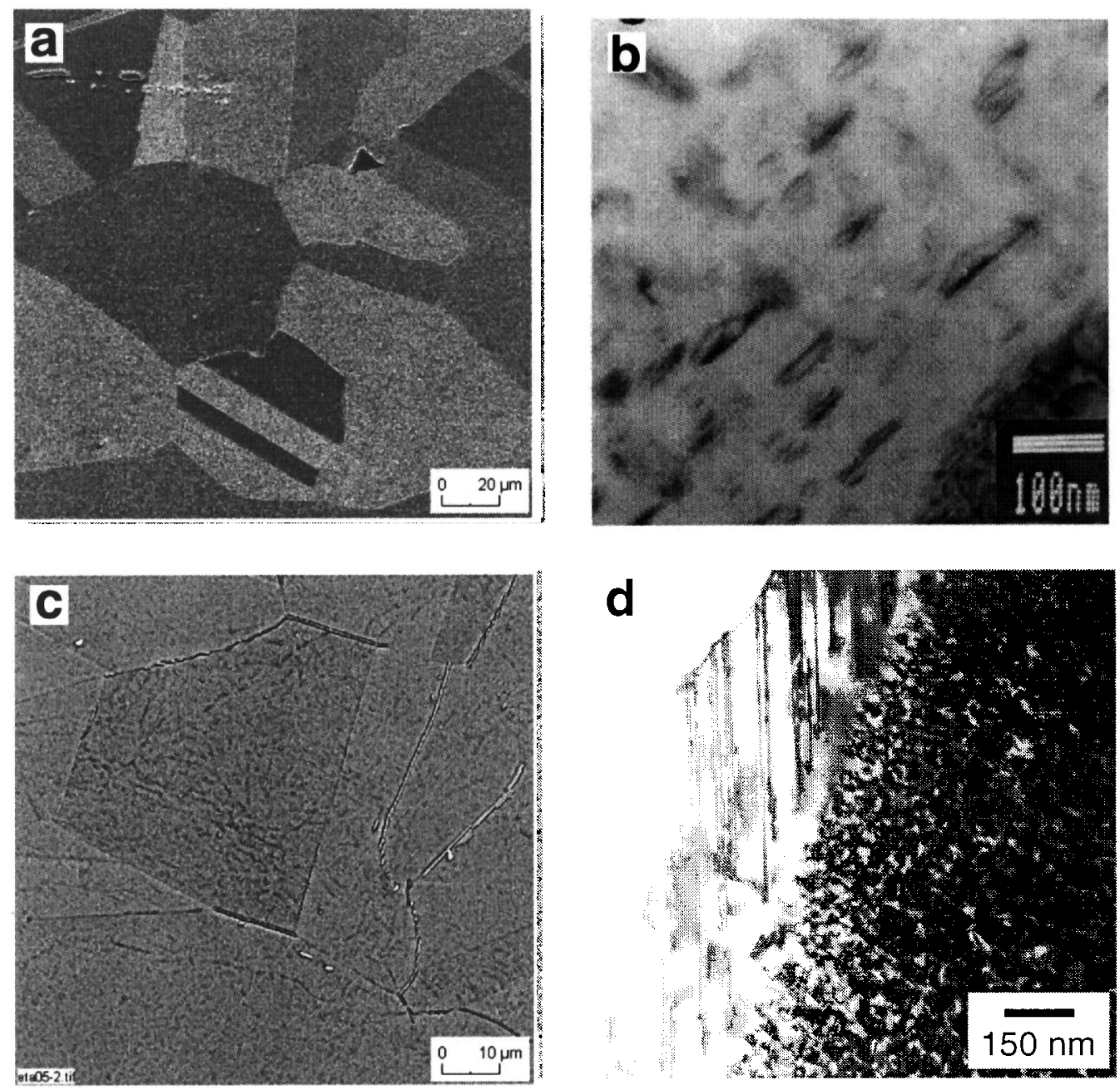

Fig. 3: Inconel 706 microstructure after direct aging $(a, b)$ and stabilization heat treatment (c,d) (see table I). Note grain boundary decoration with $\eta$-phase in ST condition (c,d) and absence of this phase after DA heat treatment (a).

In this context, it is important to consider the influence of the cooling rate from solutioning temperature on microstructure evolution. As shown in fig. 4, the hardness increases rapidly at cooling rates below about $40 \mathrm{~K} / \mathrm{min}$ [11]. The interpretation is as follows: At cooling rates of $40 \mathrm{~K} / \mathrm{min}$ and more, the supersaturated solid solution is frozen in and HV10 $\approx 150$ results at ambient temperature. In contrast, slow cooling causes $\gamma^{\prime} / \gamma^{\prime \prime}$-precipitation at around $800^{\circ} \mathrm{C}$ [10] so that the hardness increases considerably. One important consequence is that less $\eta$ forming elements are available for formation of grain boundary precipitates during the stabilization heat treatment. Noting that $4 \mathrm{~K} / \mathrm{min}$ was selected here for the ST heat treatment in order to reflect the cooling characteristic of large steam turbine components, the failure to substantially improve the creep crack growth resistance becomes understandable. Although 
discontinuous $\eta$-precipitation is observed as mentioned above, there is still a significant fraction of undecorated grain boundaries and, thus, sufficient availability of weak fracture paths.

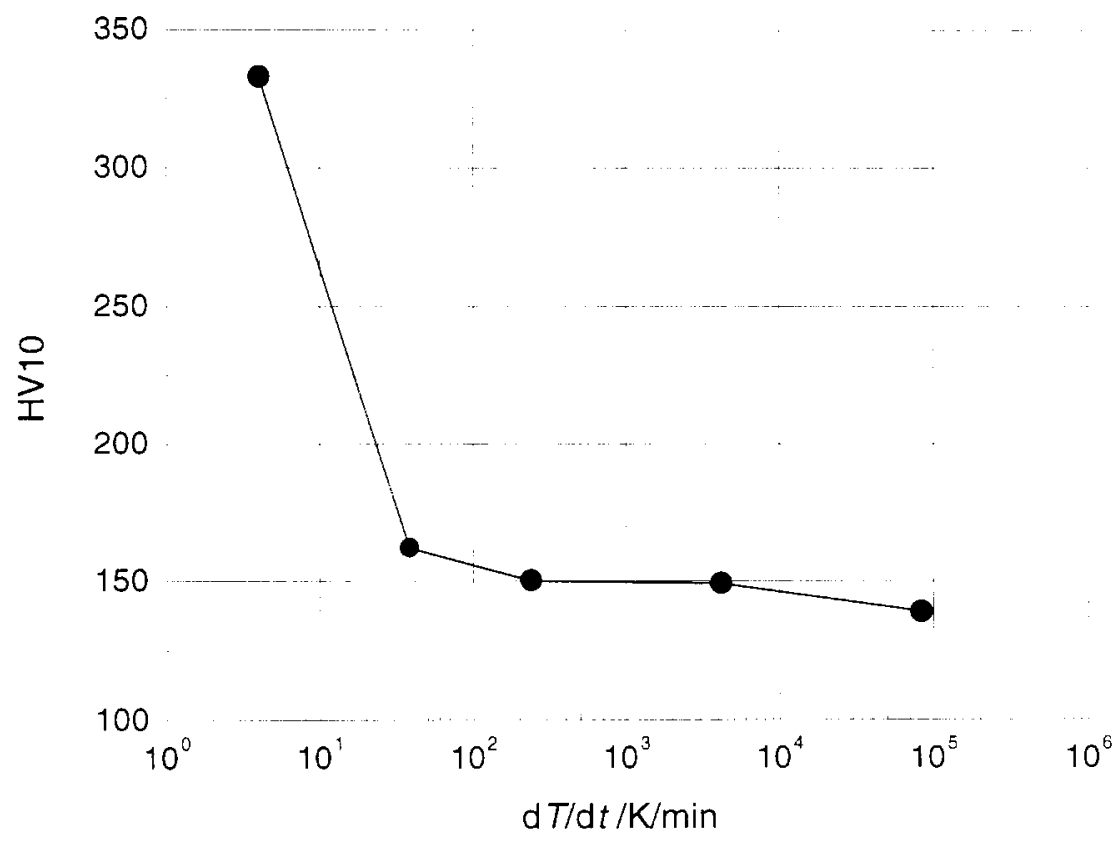

Fig. 4: Vickers hardness of Inconel 706 after cooling from solutioning at $980^{\circ} \mathrm{C}$ in dependence of cooling rate (from [11]).

Based on the above interpretation, a revised heat treatment cycle was proposed by the authors $[7,13]$, whereby cooling from solutioning is interrupted at the stabilization temperature (fig. 5) as suggested earlier for other reasons by Shibata et al. [12]. It is refered to as modified stabilization (MST) heat treatment. The idea is to prevent premature $\gamma^{\prime} / \gamma^{\prime \prime}$-precipitation upon cooling to ambient temperature so that the volume fraction of $\eta$-phase at grain boundaries is maximized. The concept is supported by creep crack growth measurements at $600^{\circ} \mathrm{C}$ showing a reduction in the crack velocity by approximately two orders of magnitude [7, 13]. However, the behavior at higher temperatures, which are more relevant for ultra high temperature steam turbine applications, has not been given comparable examination. For this reason, creep crack growth behavior of Inconel 706 is studied here at temperatures of up to $700^{\circ} \mathrm{C}$. Furthermore, comparison is made to Inconel 617 and Waspaloy as they are competing materials for the above mentioned application.

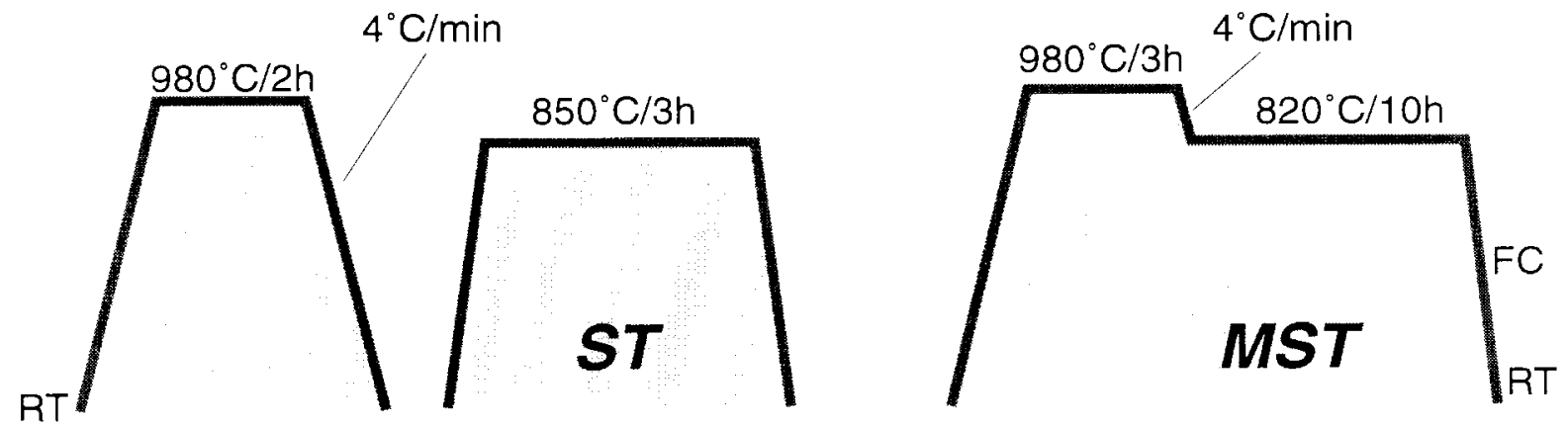

Fig. 5: Comparison of the proposed modified stabilization heat treatment cycle (MST) with the stabilization heat treatment (ST) according to standard practice. Precipitation annealing (not shown here) is identical in both cases (see table I). 


\section{Experimental Procedure}

\subsection{Materials}

The chemical composition of the alloys examined in this study is given in table II. Inconel 706 was sectioned from a triple melt gas turbine disc supplied by Alstom (Switzerland) Ltd. The material was re-annealed according to table I and fig. 5, resulting in an ASTM 5 grain size. Waspaloy and Inconel 617 were supplied by Saarschmiede GmbH Germany in form of a forged bar $(\varnothing=165 \mathrm{~mm})$ and a forged plate $(200 \mathrm{~mm}$ thickness $)$, respectively. They were VIM-ESR and VIM-VAR double melted. Heat treatment conditions and grain size are summarized in table III.

Table II: Chemical composition of the tested alloys in weight percent.

\begin{tabular}{lcccccccc}
\hline Material & & \multicolumn{10}{c}{ Composition } \\
\hline & $\mathrm{Ni}$ & $\mathrm{Fe}$ & $\mathrm{Cr}$ & $\mathrm{Co}$ & $\mathrm{Mo}$ & $\mathrm{Nb}$ & $\mathrm{Ti}$ & $\mathrm{Al}$ \\
Inconel 706 & 40,98 & $\mathrm{Bal}$ & 16,5 & 0,03 & 0,06 & 2,9 & 1,68 & 0,225 \\
& $\mathrm{C}$ & $\mathrm{Mn}$ & $\mathrm{Cu}$ & $\mathrm{S}$ & $\mathrm{Si}$ & $\mathrm{V}$ & $\mathrm{P}$ & $\mathrm{Zr}$ \\
& 0,017 & 0,08 & 0,01 & 0,00015 & 0,04 & 0,03 & $<0,005$ & 0,006 \\
& & & & & & & & \\
Inconel 617 & $\mathrm{Ni}$ & $\mathrm{Fe}$ & $\mathrm{Cr}$ & $\mathrm{Co}$ & $\mathrm{Mo}$ & $\mathrm{Nb}$ & $\mathrm{Ti}$ & $\mathrm{Al}$ \\
& $\mathrm{Bal}$. & 0,5 & 22,0 & 12,9 & 9,05 & - & 0,55 & 1,11 \\
& $\mathrm{C}$ & $\mathrm{Mn}$ & $\mathrm{Cu}$ & $\mathrm{S}$ & $\mathrm{Si}$ & $\mathrm{N}$ & $\mathrm{P}$ & $\mathrm{B}$ \\
& 0,06 & 0,03 & 0,03 & 0,001 & 0,14 & 0,015 & 0,004 & 0,001 \\
& & & & & & & & \\
Waspaloy & $\mathrm{Ni}$ & $\mathrm{Fe}$ & $\mathrm{Cr}$ & $\mathrm{Co}$ & $\mathrm{Mo}$ & $\mathrm{Nb}$ & $\mathrm{Ti}$ & $\mathrm{Al}$ \\
& 57,1 & 0,57 & 19,35 & 14,0 & 4,52 & 0,01 & 3,13 & 1,22 \\
& $\mathrm{C}$ & $\mathrm{Mn}$ & $\mathrm{Cu}$ & $\mathrm{S}$ & $\mathrm{Si}$ & $\mathrm{N}$ & $\mathrm{P}$ & $\mathrm{B}$ \\
& 0,033 & 0,05 & 0,015 & 0,0018 & 0,04 & 0,003 & 0,003 & 0,005 \\
\hline
\end{tabular}

Table III: Heat treatment conditions and grain size of Inconel 617 and Waspaloy.

\begin{tabular}{cccc}
\hline Material & Heat Treatment Step 1 & Heat Treatment Step 2 & $\begin{array}{c}\text { Grain Size } \\
\text { (ASTM) }\end{array}$ \\
\hline Waspaloy & $\begin{array}{c}4 \mathrm{~h} / 1080^{\circ} \mathrm{C} ; 4 \mathrm{~K} / \mathrm{min} \text { to } 700^{\circ} \mathrm{C} / \text { then } \mathrm{AC} \\
\text { to } \mathrm{RT}\end{array}$ & $16 \mathrm{~h} / 760^{\circ} \mathrm{C} \mathrm{AC} ;$ & 5.5 \\
Inconel 617 & $2 \mathrm{~h} / 1180^{\circ} \mathrm{C} ; 4 \mathrm{~K} / \mathrm{min}$ to $700^{\circ} \mathrm{C} /$ then $\mathrm{AC}$ & $2 \mathrm{~h} / 800^{\circ} \mathrm{C} ; \mathrm{AC}$ & 1 \\
to RT
\end{tabular}

\subsection{Creep Crack Growth Measurement}

Creep crack growth tests were performed using electromechanical testing machines equipped with a chamber furnace and 1" compact tension (CT) specimen with $2.5 \mathrm{~mm}$ deep side grooves according to ASTM E 1457-92 [9]. The fracture surface was oriented in the tangential-radial plane of the forging with crack propagation in radial direction for Inconel 706 and in the longitudinal-long transverse plane for Inconel 617. In case of Waspaloy, crack propagation direction was parallel to the bar axis. All specimen were pre-cracked under fatigue loading at room temperature. The specimen temperature, monitored by a $\mathrm{Ni}-\mathrm{NiCr}$ 
thermocouple attached to the specimen surface, was maintained within $\pm 3^{\circ} \mathrm{C}$ during testing. Crack propagation was measured by means of the potential drop technique. The crack length was calculated from the registered potential signal using Johnson's formula (see ASTM E1457-92).

\subsection{Metallography}

Specimen for microstructural investigations were prepared by mechanical grinding and polishing, followed by etching with a mixture of $100 \mathrm{ml} \mathrm{HCl}, 10 \mathrm{ml} \mathrm{HNO}_{3}, 0.3 \mathrm{ml}$ Sparbeize (trade name of Wirtz-Buehler GmbH Düsseldorf, Germany) and $100 \mathrm{ml}$ distilled water at a temperature of $40^{\circ} \mathrm{C}$. Specimen for transmission electron microscopy (TEM) were cut. punched and jet-polished at $-15^{\circ} \mathrm{C}$ using $30 \mathrm{ml}$ ethyleneglycol monobutyl ether, $63 \mathrm{ml}$ ethanol and $7 \mathrm{ml} \mathrm{HClO}_{4}$. A Philips CM12 with $120 \mathrm{kV}$ acceleration voltage was used.

\section{Results and Discussion}

\subsection{Creep Crack Growth Behavior of Inconel 706}

In fig. 6 creep crack growth data of Inconel 706 after DA and MST heat treatment are compared in the temperature range from $600^{\circ} \mathrm{C}$ to $700^{\circ} \mathrm{C}$. Interestingly, there is an acceleration of the creep crack growth rate with increasing temperature for Inconel 706-DA whereas a deceleration is observed for Inconel 706-MST. It leads to an even more pronounced benefit of the MST heat treatment at $700^{\circ} \mathrm{C}$ compared to $600^{\circ} \mathrm{C}$.

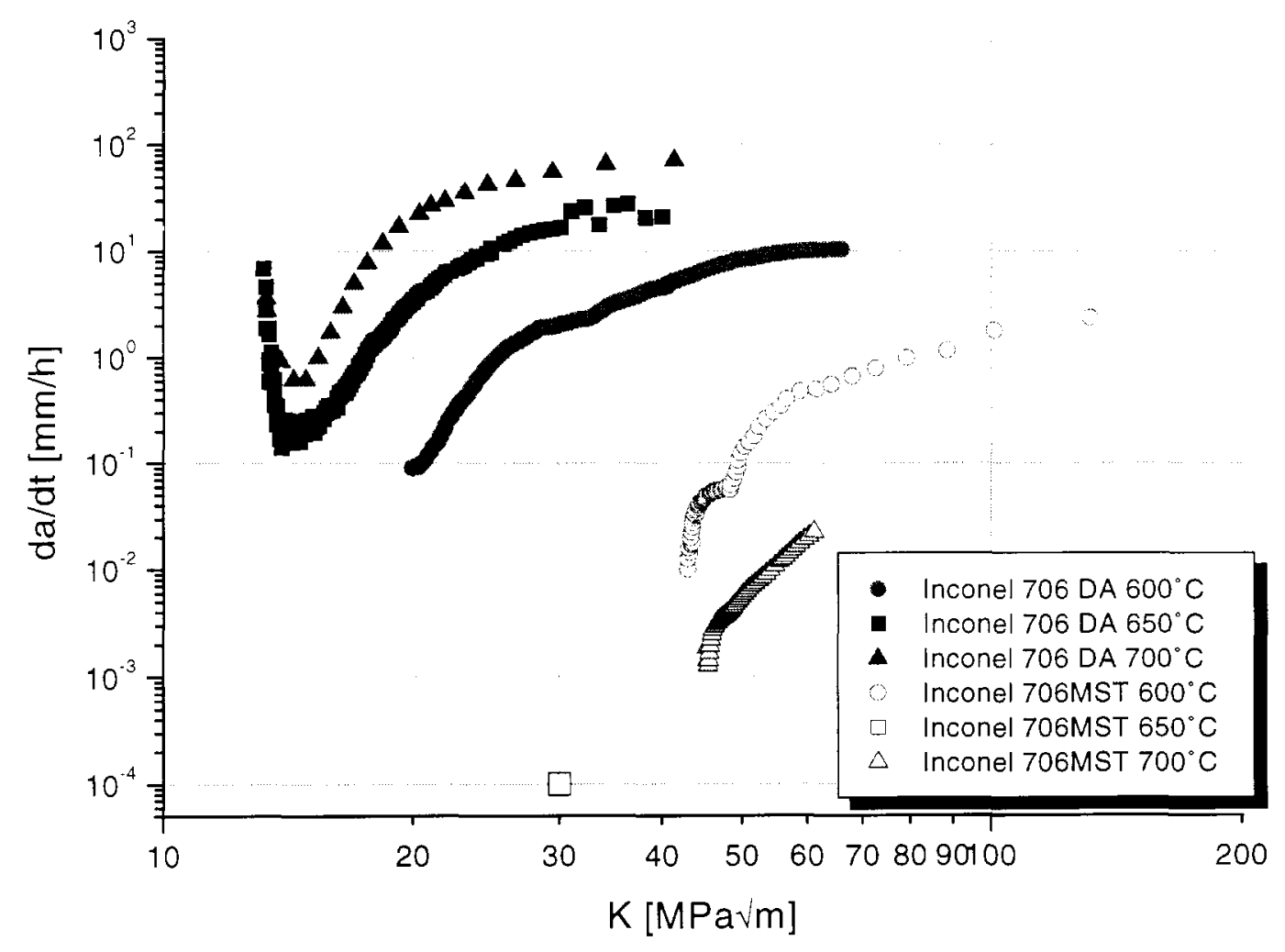

Fig. 6: $600^{\circ} \mathrm{C}$ to $700^{\circ} \mathrm{C}$ creep crack growth data for Inconel 706 in DA and MST heat treatment condition (see table I and fig. 5).

In this context, two effects have to be considered, namely environmental embrittlement by ingress of oxygen along grain boundaries and, on the other hand, creep deformation at the 
crack tip [14]. In cases where crack growth is entirely controlled by the first mechanism (creep brittle materials), the crack propagation rate is expected to increase with oxygen diffusivity, i.e. temperature, provided the type of the oxide scale at the crack surface does not change with temperature. However, the situation is less clear when creep deformation becomes significant. It may lead to an acceleration because of damage accumulation in front of the crack tip or a deceleration as stresses are diminished by crack tip blunting. Inconel 706DA clearly belongs to the category of creep brittle materials, showing no discernible crack tip plasticity in the temperature range examined here. This behavior is understandable in view of the extremely high crack propagation rates of up to $100 \mathrm{~mm} / \mathrm{h}$ and the fine precipitate morphology, causing high yield strength levels. In contrast, Inconel 706-MST shows signs of creep deformation at $700^{\circ} \mathrm{C}$ in front of the crack tip (fig. 7), even though fracture is still intercrystalline. Thus, two factors appear to be responsible for the observed improvement in creep crack growth resistance. Firstly, it stands to reason that the discontinuous $\eta$-precipitates improve grain boundary "locking" and inhibit grain boundary sliding much as carbides do in cast $\mathrm{Ni}$-base superalloys. Secondly, there is a general reduction in yield strength due to microstructure coarsening at $850^{\circ} \mathrm{C}$ and a local softening of the grain boundary regions as precipitate free zones evolve around $\eta$-precipitates (fig. $3 \mathrm{~d}$ ). Both factors, the enhancement of the material resistance against crack propagation along grain boundaries and the reduced strength, are responsible for the observed creep ductility in MST condition and it seems that the positive effect (reduction of the crack tip stresses) overrides the material weakening by cavity formation. As mentioned above, the ST heat treatment is significantly less effective than the MST treatment because of incomplete grain boundary decoration with $\eta$-phase.

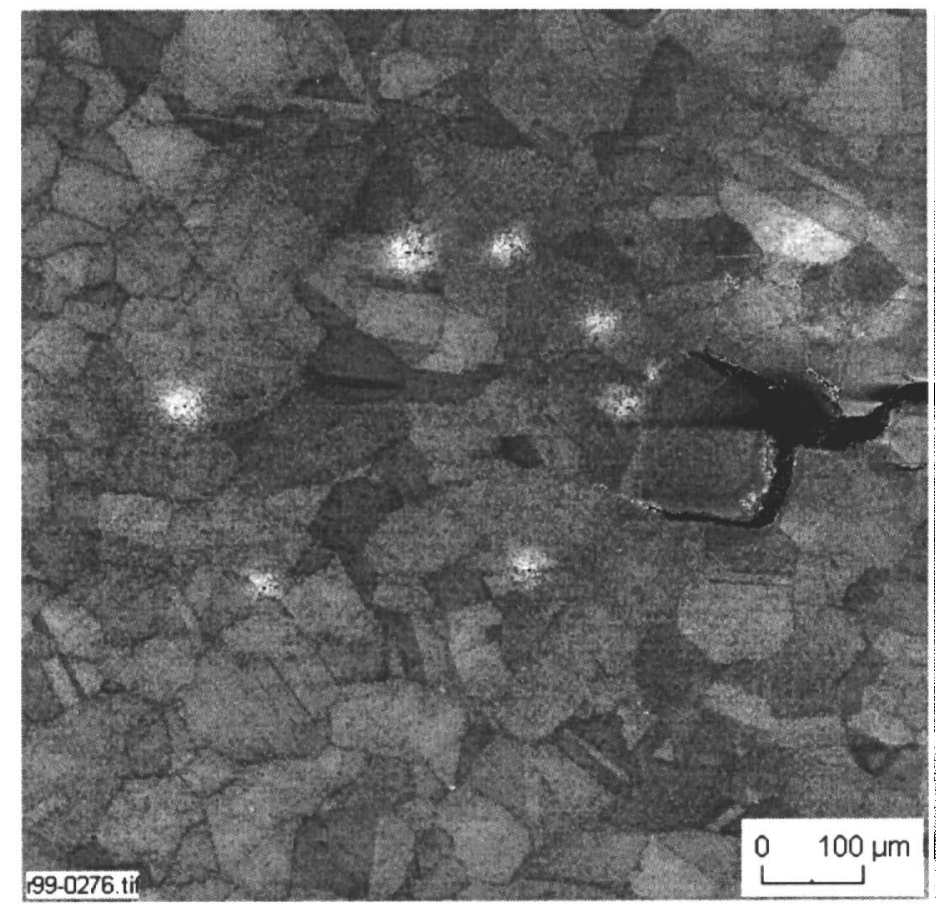

Fig. 7: Crack tip region of Inconel 706-MST after 2000h / $700^{\circ} \mathrm{C}$ creep crack growth $\left(\mathrm{K}_{\text {initial }}=26.5 \mathrm{MPam}^{1 / 2}\right)$. Note creep damage ahead of the crack tip.

\subsection{Comparison with Inconel 617 and Waspaloy}

As indicated above, Inconel 617 and Waspaloy are also candidates for application in ultra high temperature steam turbine plants. While Inconel 706 is a typical representative of $\gamma^{\prime} / \gamma^{\prime \prime}$ - 
strengthened wrought alloys, Waspaloy belongs to the class of $\gamma^{\prime}$-hardened materials. Inconel 617 is essentially solid solution and carbide strengthened. Amongst the three materials, Waspaloy exhibits by far the highest creep strength but also Inconel 617 is expected to show superior long term strength to 200000 operation hours because of its better microstructural stability [15]. On the other hand, manufacturability is best for Inconel 706. Due to significant solid solution strengthening, forgeability of Waspaloy and Inconel 617 is inferior. Furthermore, freckling is an issue for large Waspaloy components as segregation of aluminum and titanium in the interdendritic liquid tends to cause a density inversion which is the reason for freckling. In view of the intended application it is also of interest to compare the creep crack growth behavior of the three materials which was the motivation for this study.

Creep crack growth data at $700^{\circ} \mathrm{C}$ are shown in fig. 8 for all three materials. Clearly, Inconel 706-DA is far inferior to Waspaloy and Inconel 617. This is understandable in view of the above discussion because grain boundaries of Waspaloy and Inconel 617 are stabilized by carbides and $\gamma^{\prime}$-precipitates (Waspaloy), whereas Inconel 706-DA is devoid of any grain boundary strengthening phase. Considering furthermore that Inconel 617 exhibits the largest grain size (see table III), highest creep ductility and lowest strength, it also becomes understandable why this material shows best creep crack growth resistance. Figure 8 also illustrates the huge benefit of the proposed heat treatment modification for Inconel 706. In MST condition, the creep crack growth rate is very similar to that of Waspaloy. Thus. it seems that the various grain boundary strengtheners (carbides, $\gamma^{\prime}$ - and $\eta$-phase) are of similar benefit. From this point of view, Inconel 706-MST seems well suited for ultra high temperature steam turbine applications provided microstructure degradation during long term service is tolerable (see e.g. [15]).

To understand the effect of microstructure coarsening on creep crack growth resistance, test samples have been heat treated for $5000 \mathrm{~h} / 750^{\circ} \mathrm{C}$ at IfW Darmstadt. The accelerated treatment is roughly equivalent to $100000 \mathrm{~h}$ at $700^{\circ} \mathrm{C}$ which is a mid-of-life condition for prospective steam turbine components. Interestingly, Inconel $706-\mathrm{DA}-5000 \mathrm{~h} / 750^{\circ} \mathrm{C}(=$ Inconel $706-\mathrm{DA}$ after exposure at $5000 \mathrm{~h} / 750^{\circ} \mathrm{C}$ ) exhibits significantly improved creep crack growth resistance. It is a consequence of the microstructural coarsening (reduced strength) and $\eta$-precipitation at grain boundaries (fig. 9). However, the behavior is still inferior to Inconel 706-MST.

The above result allows two interpretations: one may argue that microstructural coarsening during extended high temperature exposure overrides initial microstructure differences obtained after DA and MST heat treatment. Then, it would be expected that Inconel 706-MST degrades to the properties of $706-\mathrm{DA}-5000 \mathrm{~h} / 750^{\circ} \mathrm{C}$. However, it is also possible that precipitate morphologies differ even after extended exposure. For example, it is imaginable that initial nucleation of $\gamma^{\prime} / \gamma^{\prime \prime}$ in the grain interior at $700^{\circ} \mathrm{C}-750^{\circ} \mathrm{C}$ diminishes heterogeneous $\eta$-phase formation at grain boundaries. In fact, it seems that extended exposure at $750^{\circ} \mathrm{C}$ leads to more pronounced formation of film like precipitates (fig. 9) compared to MST heat treated samples. Consequently, one would expect a distinct advantage of Inconel 706-MST in terms of creep crack growth resistance even after long term operation. Further heat treatment experiments are underway to clarify this open issue.

Heat treatment effects are less pronounced in case of Inconel 617 and Waspaloy, reflecting their superior microstructural stability in the heat treatment range under investigation. However, the trends appear to be in opposite direction. While crack growth resistance seems to increase somewhat for Waspaloy, fig. 8 indicates a slightly accelerated crack velocity for 
Inconel $617-5000 \mathrm{~h} / 750^{\circ} \mathrm{C}$ towards high stress intensities. Further tests are underway to verify this first impression.
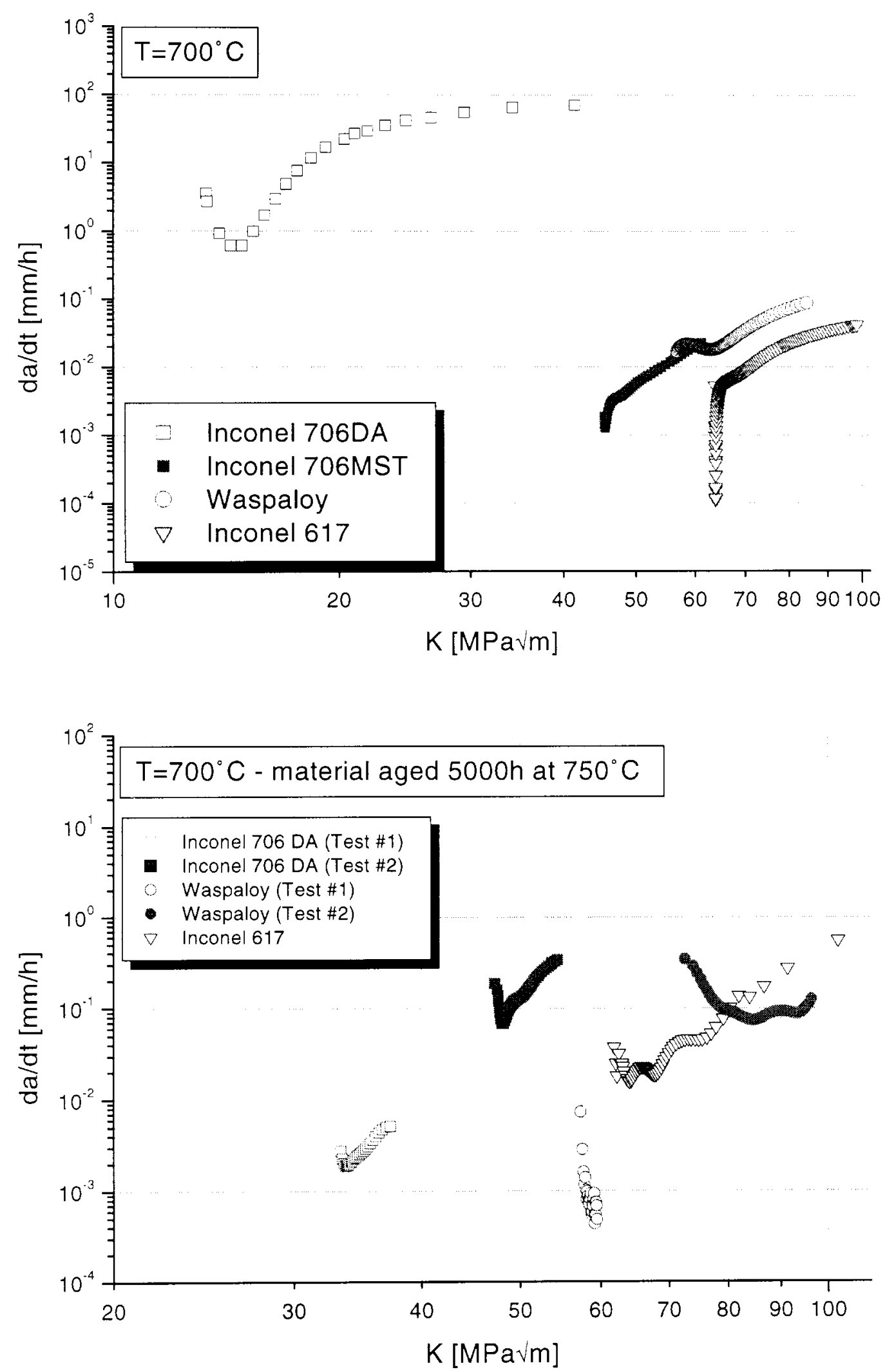

Fig. 8a,b: Creep crack growth data for Inconel 706, Inconel 617 and Waspaloy at $700^{\circ} \mathrm{C}$. Shown are results after full heat treatment (a) and aging at $5000 \mathrm{~h} / 750^{\circ} \mathrm{C}$ (b). 

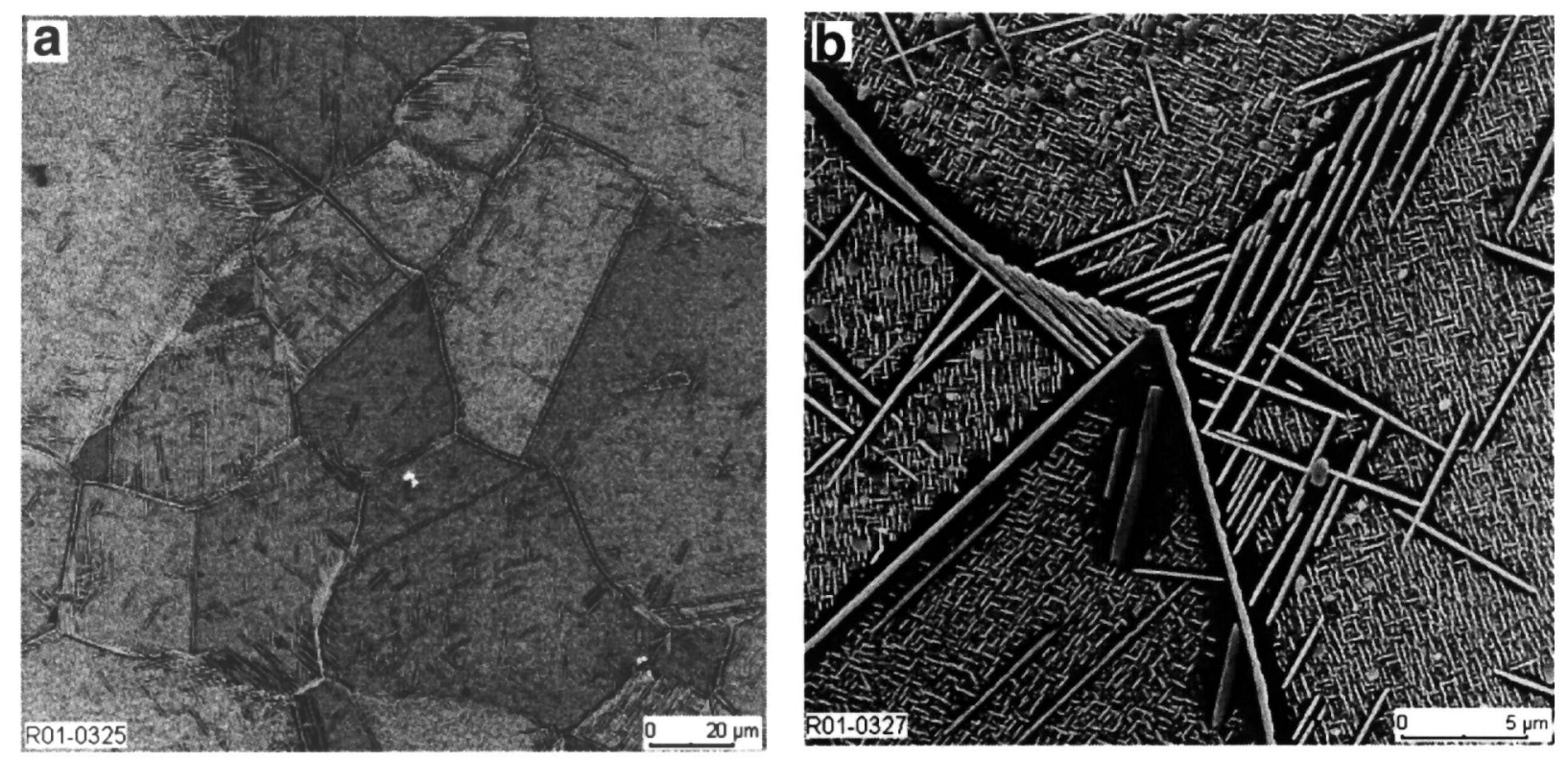

Fig. 9: Microstructure of Inconel 706-DA after aging at $750^{\circ} \mathrm{C} / 5000 \mathrm{~h}$. Note two types of $\eta$ precipitation at grain boundaries: film like (lower left corner of fig. b) and cellular (upper right corner of fig. b). In (b), a magnified section of (a) is shown.

\section{Conclusions}

The creep crack growth behavior of Inconel 706 was studied in dependence of heat treatment condition and compared to Waspaloy and Inconel 617. It was demonstrated that the so-called MST heat treatment modification, proposed earlier by the authors [7, 13], leads to very satisfactory results over the entire temperature range studied here $\left(600^{\circ} \mathrm{C}\right.$ to $\left.700^{\circ} \mathrm{C}\right)$. Compared to conventional heat treatment conditions, crack velocities are reduced by two to four orders of magnitude and the creep crack growth resistance becomes similar to that of Waspaloy and Inconel 617. "Locking" of the grain boundaries by $\eta$-precipitates as well as strength reduction due to microstructural coarsening appear to be the most important factors. Despite these encouraging results, there remain also a number of open issues for applications beyond $600^{\circ} \mathrm{C}$. In particular, it is presently unclear whether the creep crack growth resistance of Inconel 706-MST can be maintained after extended operation of up to 200000h. This aspect is currently under further evaluation.

\section{Acknowlegement}

The authors would like to thank the Deutsche Forschungsgemeinschaft, Germany, for financial support. Material supply by Alstom (Switzerland) Ltd. and Saarschmiede GmbH Germany is also greatly appreciated. Furthermore we would like to thank Dr. Penkalla, Forschungszentrum Jülich, for support with the TEM investigations. 
1. P.W. Schilke, J.J. Pepe and R.C. Schwant, "Alloy 706 Metallurgy and Turbine Wheel Application", Superalloys 718, 625, 706 and Various Derivatives, ed. E.A. Loria (Warrendale, PA: TMS, 1994), 1-12.

2. G. Härkegard and J.Y. Guedou, "Disc Materials for Advanced Gas Turbines", Materials for Advanced Power Engineering, ed. J.Lecomte-Beckers et al. (Jülich: Forschungszentrum Jülich, 1998), 913-931.

3. E. Andrieu et al., "Oxidation Mechanisms in Relation to High Temperature Fatigue Crack Growth Properties of Alloy 718", Superalloys 718, 625, 706 and Various Derivatives, ed. E.A.Loria (Warrendale, PA: TMS, 1994), 619-631.

4. D.A. Woodford and R.H. Bricknell, "Grain Boundary Penetration of Oxygen in Nickel and the Effect of Boron Additions", Metall. Trans.. 12A (1981), 1467-1475.

5. D.F. Smith and J.S. Smith, Physical Metallurgy of Controlled Expansion Invar-Type Alloys, ed. K.C.Russell and D.F.Smith (Warrendale, PA: TMS, 1990) 253.

6. P.F. Browning, M.F. Henry and K. Rajan, "Oxidation Mechanisms in Relation to High Temperature Crack Propagation Properties of Alloy 718 in $\mathrm{H} 2 / \mathrm{H} 2 \mathrm{O} / \mathrm{Inert}$ Gas Environment", Superalloy 718, 625, 706 and Various Derivatives, ed. E.A.Loria (Warrendale, PA: TMS, 1997), 665-678.

7. S. Müller and J. Rösler, Life Assessment of Hot Section Gas Turbine Components, ed. R. Townsend et al. (Cambrigde: Cambridge University Press, 1999), 49.

8. J. Rösler and S. Müller, "Protection of Ni-Base Superalloys against Stress Accelerated Grain Boundary Oxidation (SAGBO) by Grain Boundary Chemistry Modification", Scripta mat., 40 (1999), 257-263.

9. ASTM E 1457-92, Standard Test Method for measurement of creep crack growth rates in metals (American Society for Testing and Materials, 1992).

10. K.A. Heck, "The Time-Temperature Transformation of Alloy 706", Superalloys 718. 625, 706 and various derivatives, ed. E.A. Loria (Warrendale, PA: TMS, 1994), 393-404.

11. S. Müller, Kriechrisswachstum in Inconel 706, Fortschritt-Berichte VDI, Reihe 5, Nr. 594 (Düsseldorf: VDI, 2000).

12. T. Shibata et al., "Effect of Cooling Rate from Solution Treatment on Precipitation Behavior and Mechanical Properties of Alloy 706", Superalloys 718, 625, 706 and various derivatives, ed. E.A. Loria (Warrendale, PA: TMS, 1997), 379-388.

13. S. Müller and J. Rösler, Steels and Materials for Power Plants, vol. 7, ed. P. Neumann and D. Allen (WILEY-VCH-Verlag, 1999), 352.

14. K. Sadananda and P. Shahinian, "Creep Crack Growth Behavior of Several Structural Alloys", Met. Trans., 14A (1983), 1467-1480.

15. C. Berger et al., "Zeitstand- und Kriechrissverhalten von Nickellegierungen für $700^{\circ} \mathrm{C}$ Dampfturbinen", 23. Vortragsband der Arbeitsgemeinschaft für warmfeste Stähle und Hochtemperaturwerkstoffe (Düsseldorf: VDEh, 2000), 103-115. 